\title{
Socio-lingual Phenomenon of the Anti-language of Polish and American Prison Inmates
}

\begin{abstract}
The aim of this paper is to compare Polish and American prison slang terms as well as their inmate codes. This paper is devoted to the phenomenon of prison subculture from the perspective of the Polish prison slang so called the secret grypserka language (from gryps - a slang word meaning a letter smuggled into or out of a jail). Grypserka is the anti-language of Polish prison inmates. Prisoners are people, too, like doctors, policemen and undertakers but when being in prison they lose their friends or often family and then there is nothing left for them but to learn words (grypserka slang) in order to communicate secretly with one another. Perhaps, nobody wants to be sentenced to prison apart from those who are broken-down. A lot of people regard imprisonment as the end of the world. In spite of their dislike or even fear of prisons, they do not close the way to experience power, wealth, sex and addiction. In order to gain so many conveniences, prisoners have to develop their language skills and learn grypserka which allow many desires to be met in their "second world" relieving the pains and inconveniences of incarceration.

All in all, it was agreed that "the distinctive argot of inmates gives an insight into the institutions, preoccupations, and style of prison life" (Michaels and Ricks, 1980: 525). Unfortunately, the prison slang has a negative effect on the rehabilitation process because it carries subculture "essence" - rules and norms. It is due to unique expressions, words and phrases that the way of thinking and outlooks of the group members are shaped. When penetrating such a composite phenomenon as the prison slang one should take into consideration its specific attribute - secrecy - and, moreover, the fact that its chief goal is to fight against law.
\end{abstract}

Keywords: Prison slang, grypserka, Polish prison subculture, anti-language, American and Polish prison terminology.

\section{The concept of "prisonization"}

First of all, the difference between socialization and prisonization needs to be explained at this point. Socialization refers to the process whereby one adopts the values, behaviours, and norms of the subculture, prisonization may be referred to as the process whereby inmates become so acclimated to prison life that the free world becomes strange and the prison becomes normal (Pollock, 2005: 102).

There are different types of adaptations among inmates. Goffman (1961: 61-63) divided them into situational withdrawal, intransigent line, colonization and conversion. "Situational withdraw- 
al" was characterized by a removal and alienation from prison life. Clemmer (1958) first described "situational withdrawal" inmates and labeled them "ungrouped" - those who play a solidary or semisolidary role in the prison environment. Przybylski (2005: 28) calls them "niegrypsujący" or "nieludzie" meaning "non-humans". "Intransigent line" inmates were those who bucked the system and intentionally challenged the institutional regime by flagrantly refusing any and all cooperation with staff members. Schrag (1944) calls them "outlaw" inmates, Giallombardo (1966) "jive bitches". "Colonized" inmates were described by Goffman as those who maximized the perks allowed in prison and created their whole world out of them. Przybyliński’s (2005: 28) "grypsujący, ludzie, git-ludzie" meaning "humans" or "cool humans" seem to come close to this role. Schrag (1944) calls them "con-politicians". Colonized inmates may be considered the most prisonized because it appears that they have come to accept prison as home. At last "converted inmates" are those that had completed the institutional role and were described as the "perfect inmate" by staff, jailers and administrators, but not by inmates (Goffman, 1961: 63). The colonized inmates are called by other prisoners a "suck ass" or a "led rider" and are equivalents to Przybyliński's (2005: 28-34) "poszkodowani" or "cwele" meaning "victims" or "faggots". The colonized inmates are called by Giallombardo (1966) "inmate cops" and by Sykes (1958) "centermen". In the Polish prison history, the term "grypserzy" - those who accepted the rules of prison life, has many different names. From 1965 to 1966 the most popular term for "grypserzy" was "urkowie". Urkowie came from Warsaw and used to be treated as those having power over other prisoners. They were considered dangerous and disruptive. In 1965-1966 the word "urkowie" faded and was replaced by "charakterniak" describing a person having a strong character. In 1967 there appeared a new word "ludzie" or "git-ludzie" meaning "humans" or "cool humans" and these terms are still in use (Przybyliński, 2005: 29)

Clemmer (1958: 301) cites the following factors affecting prisonization: "long sentences, unstable personality, few positive relations with outside people, readiness to join prison primary groups, a blind acceptance to the mores of the primary group, chance placement with similar others in prison, and readiness to participate in gambling and "abnormal" sexual behavior". 2 The prison subculture has been described as an underground organization replete with its own codes of rules and terminology and, therefore, one more factor affecting the process of prisonization should be mentioned. That is readiness to learn prison argot or grypserka.

\section{Defining Prison Subculture}

The field of subcultural research has been subject to wide number of methodological, theoretical and ideological debate. In reading subcultural research one must be aware not only of biases inherent in the research but also the prejudices the reader brings to the reading. Subcultural research calls on a variety of sociological theory; from early studies of deviance to the post-modern 
to conceptions of a networked society. The exploration of subcultures often commences with particular definition of subculture. Although the validity of such a task is questionable, it nonetheless provides a means to begin exploration of the topic.

Subculture can be understood as a group of individuals having distinctive attributes that is distinguishable from others within the same society (Fowler, 1964). Such an ambiguous definition provides a reasonable launching point at which to address such a complex subject matter. On reading such a definition one may be provoked to consider a number of counter definitions that essentially negate the properties of the original definition.

The definitional problems of subculture can be recognised in many research projects undertaken in the field of subcultural research. Becker (1963) undertook the study of jazz musicians to understand the conflicts that arose between musicians, employers and the audience. Stallybrass et al. (1986) reconceptualised the festival of canivale from being defined as a popular festival to a subcultural dialectic between the conventional and the unconventional. Jenkins (1992) on television fan culture, Crimp et al. (1990) on AIDS activism and Fonarow (1995) on live music events all demonstrate how broad conceptions of subcultures may be.

Thornton (1997: 1) introduces the question of subculture by comparing it to relating concepts such as "the masses", "the public", "society" and "culture". Thornton's (1997: 5) comparison sheds light on the practice of subcultural research as being a process of construction, which labels, frames and demarcates, relying heavily on ill-conceived concepts as a definitional base. Early research projects on the nature of subcultural deviance tend to deploy this problematic most seriously (Thornton, 1997: 6).

Early investigations into subcultures tended to engage in a broad descriptive process, often appearing to be lost in the complexities and never-ceasing questions that developed from their observations. Hebdige (1979: 75) traces subcultural research as far back as the nineteenth century to urban ethnographies, written by the likes of Mayhew (1851), Archer (1985) Dickens (1984) and Morrison (1946), which employed descriptive methodologies without scientific orientations. The earliest sociological investigation of subcultures can be found in the works of Thrasher (1963), who investigated 1,313 gangs of Chicago to comprehend "gangland" environment, patterns of gang behaviour and problems of delinquency control. Research was undertaken through participant observation which produced a fantastic depth of description. However, Hebdige (1979: 75) has criticized such works as lacking "any analytical or explanatory framework." Although the accuracy of Thrasher's research is certainly debatable Hebdige's criticism may be too harsh for such an early, insightful piece of sociological research.

Chicago University carried out similar work to Thrasher (1963). Notable researchers that engaged in subcultural research at Chicago University included Park (1925), Cohen (1955), Cressey (1932), Becker (1963) and Young (1971). Park (1925) outlined the major theoretical direction that would be undertaken by Chicago University in subcultural research. Such explorations were to include "customs, beliefs, social practices, conceptions of life and the manners of urban life" (Thornton, 1997: 11). An early article produced by Park (1925) called on other sociologists to ex- 
plore the urban environment in a similar way to anthropologists like Franz Boas, Robert Lowie and Emile Zola. Park's "The City" draws out the complexities of subculture and sets out over fifty speculative questions and queries for his readers to consider. A less appealing yet more succinct theoretical direction was produced by Albert Cohen (1955). Cohen (1955: 59) suggested that subcultural investigation investigate subcultures as if they were "a series of effort to solve problems." Cohen (1955) argued that subcultures were the product of cultural formations that involved a number of actors interacting in order to solve problems of adjustment. Cohen excluded any empirical undertakings from this postulation and tended to rely on preconceived notions of human nature to form his argument. Most incredible is the significant departure Cohen takes from the imaginative work of Park. Cohen attempts to construct a grand narrative for subcultures that typically eroded the complexities to be investigated and focused on deterministic operators such as subculture as "problem solvers".

Unfortunately, such reductive theoretical frameworks only increase after Cohen (1955) publication. Phil Cohen (1972) was a participant at Birmingham Universities centre for contemporary cultural studies who produced a similar yet more influential work on subcultural theory. The research undertaken at this centre was largely influenced by the earlier work of Chicago University however the centre soon moved well beyond these influences to construct an elaborate re-thinking of subcultural theory that was able to incorporate theories of capitalism into the analysis of subculture (Thorton, 1997: 15; Gelder, 1997: 83). Research at the centre focused on the relationship between ideology and structure found predominantly within working-class youth subcultures (Gelder, 1997: 83). The latter works of the centre, especially those of Dick Hebdige (1979), specifically focused on subcultural structures of style as a means to demonstrate the relationships between youth subcultures and conflict, contradiction and the complexities of working-class.

This relationship between youth subculture and working-class culture is explored by Phil Cohen (1972) in his work "subcultural conflict and working-class community". Cohen begins his exploration by analysing the work of the planning authority of east London in 1955. Cohen (1972: 90) noted that the overall plan for the community was to redevelop slumping real-estate into high density apartments. The desired effect of this change was supposed to elevate the community beyond their current material limits. However, Cohen (1972: 91) argued that this specific change led to the ultimate destablisation of the community. Cohen (1972: 92-93) explored how break-downs in the material structure of the neighborhood left individual families isolated from extended kin-networks, evaluated industrial changes to demonstrate the removal of traditional patterns of socialisation, and argued that the ultimate culmination these changes was the development of a generational battleground between parent and child.

Cohen (1972: 94) described a generational conflict as the movement of interpersonal conflict from a family setting into a collective environment as means to diffuse tension and anxiety that may develop directly between family members. In other words, Cohen (1972: 94) believed that generational conflicts lead directly to the creation of subcultures. For Cohen, youth subcultures can be seen as being involved in a generational conflict as they contain generational specific sym- 
bols that functions to "express and resolve the contradictions hidden in a parent culture". Cohen argued that the contradictions found in the East End included a double bind between a protestant work-ethics and consumption values and a similar bind between aspirations for mobility and class identification. In East End youth subcultures, such as "Mods", "Skinheads" and "Crombies", Cohen (1972: 95) argued that symbolic systems and rituatualised activities functioned to either draw out or overcome contradictions found within working-class culture.

Generally, the majority of Cohen's work can be seen as emphasising symbolism, ritualised forms of resistance and how these relate to working-class parent-culture and mass culture (Gelder, 1997: 145). Instead of addressing specific attributes of subculture as his primary source of data Cohen analyses economic infrastructure and concludes that class-conflict must be the major force in constructing subculture. The major problem with this approach is that the research unknowingly imparts ideological biases onto a subculture which may not contain such ideological interests. Cohen often describes particular subcultures as uniform structures that play out an almost scripted narrative of resistance. Through valuing the structural institutions over and above individual agency and interest Cohen defines an individual as being the exclusive product of class while paying little attention to other social and personal attributes. Clarke (1981: 176) argues that Cohen's insight into subcultures often lack a significant comprehension of how subcultures are initially formed, "transformed, appropriated, disfigured and destroyed." Cohen's (1972: 94) analysis often abstracts the agency of an individual to simply bearing and supporting the predefined outcomes of the subculture. And Cohen's work has been widely critiqued for being unable to provide a complete picture of various forms of subculture.

However, Cohen himself has provided alternatives to the narrow framework he constructed earlier in his research. During the 1980s Cohen reworked a large body of his subcultural framework to allow for the incorporation of external entities, such as the media, into the construction of subcultures. Such reconceptualisation allowed for the introduction of (subculture-specific) structural influences into subcultural theory and acted as a catalyst to further the constitution a subculture while allowing for a broader scope of analysis that captured the complexities of subcultures.

Significant alternatives have arisen since Cohen's publication in 1972. The general thrust of many of these theorists has been towards treating subcultures as fluid and mobile entities, although theorists have even returned to early Chicago school models (Gelder, 1997: 148). The work of Maffesoli (1996), for instance, has been largely adopted as a platform to construct a framework for the study of subcultures that is able to overcome the deterministic qualities of Cohen's work. These works typically focus on the consumption patterns, levels of access and mobility and the configuration of individuals in subcultures as related to other entities within society. For example, Ueno (2003: 112) examines "trans-local contexts" found in Rave culture to demonstrate how subcultures relate to locality, foreignness, space and the other. Or Valdivia's (2003: 151) placement of subculture as a "fluidity, hybridity and collaboration located between a 'substream' and 'mainstream' of commercialised culture." And finally, the advent technological environments have focused some subcultural research on the properties of communication and the relationships 
formed within technological mediums (Hodkinson, 2003). Essentially, these groups have been able to move beyond the deterministic models of researchers, provided by the like of Cohen (1972), to capture and comprehend the complexity that may be found in within subcultures.

The problem of definition catapults subcultural research towards an ambiguous area. The research boundaries of a subculture become blurred and the notion of a subculture itself is difficult to distinguish from other groups in society. Early subcultural researchers, such as Thrasher (1963) and Park (1925), attempted to devise a research model that was capable of grasping the complexities of urban life. However, this task was soon undermined as researchers began to impart specific ideological interests upon subculture. This is not to wholly negate the value of theorists such as Cohen (1955) and Cohen (1972) but rather just to indicate the problem that ideological approaches bring to research. In Cohen (1972) we can recognize how a top-down theoretical framework removes a number of complexities found within individuals and subcultures. However, these theoretical problems are overcome in more "post-modern" works that focus on networks, relationship and the notion of fluidity. We can recognize that these works are able to capture the nuances of subcultures while also providing a theoretical scope that is slightly ideological but mostly descriptive.

Data collection methods have located within the works of some theorists discussed in this article have orientated my empirical leanings towards a framework that will be able to capture the complexities of a subculture starting from local contexts and examining what wide forces intersect within those contexts. A number of the progressive articles that were briefly mentioned in this article demonstrate the need for a carefully devised research model that will be able to gain access to the very sensibilities of subcultural participants and a firm understanding of the vast number of structural influences that may coincide. The research model must also be aware of what ideological terms, frames and preconceptions are imparted on the subject matter. To this extent, it appears that the comprehension of subcultures will be a difficult undertaking, particularly in devising a thorough research model that will be able to capture a vast variety of subcultural elements. The ultimate solution would be to limit the investigation of subcultures to one specific attribute, such as style, networks, or consumption, yet I am sure even these seemingly simplified topics would be laden with an expansive complexity and an unending source of intrigue.

Apart from the public norms and ways of behaviour issued by a superior there is also another lifestyle in prison opposed to the aims of rehabilitation. These are norms controlling behaviour in prison called "second life". Jedlewski (1971) defines the term "second life" as "some forms of behaviour that are behind regulations determined in the process of interaction between prisoners." "Second life" is a set of uncontrolled norms. These norms specify how to behave in certain situations and live in isolation. Moczydłowski (1988: 163) claims that "the appearance of a subcultural regulator was necessary. We do something in secret so that the new culture must be created"

The prison subculture or also "grypsera" is defined by Morawski (1968: 39-44) as a "special language (prison argot)". Stępniak (1973: 213) analyses the terms "grypsera" (also "grypserka") in the criminal environment in different parts of Poland and defines them as a "prison argot and youth slang". It is very difficult to define the origin of "grypsera" due to the complete lack of any men- 
tions of this term in penitentiary literature. Śliwowski (1972: 104) states that "the issue of second life was noticed at the end of the forties and at the beginning of the fifties not only in Poland but also around the world". Grypsera derived from Warsaw and the location of the origin used to be a prison called "Gęsiówka". After a few years grypsera was spread all over Poland, especially in big prisons for young people in Warsaw, Łódź, Wrocław.

\section{Data and Method}

The data for comparing Polish and American inmate codes is from The Inmate Social System (Sykes and Messinger, 1960), The mix: The culture of imprisoned women (Owen and MacKenzie, 2004) and Life without parole: living in prison today (Hassine, 1999). Data relating to Polish inmate codes is taken from Tajemnice grypserki (Szaszkiewicz, 1997). Samples for analyzing the difference in meaning between Polish and American prison terminology were taken from The prison community (Clemmer, 1958), Texas prisons: the largest hotel chain in Texas (Glenn, 2001) and Tajemnice grypserki (Szaszkiewicz, 1997).

The research is based on a comparative method as a way to compare two forms of prison slangs (American prison slang and Polish "grypserka" slang) and the meaning of inmate codes.

\section{Comparing different inmate codes}

The inmate code is a set of rules by which prisoners should run their lives in the prison setting. Not all inmates followed such a code because it is impossible for a group of most dangerous and violent criminals who were unable to follow public rules to follow an inmate code. However, most of them subscribed to these rules. The inmate code as well as special terminology is a part of prison subculture. Giallombardo (1966) conducted research of Alderson, a prison for women to find that such a code did exist. Sykes and Messinger (1960) introduced the following inmate code:

Don't interfere with inmate interests.

Never rat on a con.

Don't be nosy.

Keep off a man's back.

Don't put a guy on the spot.

Be loyal to your class.

Be cool.

Do your own time.

Don't bring heat.

Don't exploit inmates.

Don't cop out.

Be tough.

Be a man.

Never talk to a screw.

Have a connection.

Be sharp. (Sykes and Messinger, 1960) 
Some additional features of the female uncovered by Owen and MacKenzie (2004: 159) are: Mind your own business.

The police are not your friend; stay out of their face.

If asked to do something (by staff), you do not tell.

Do not allow rat-packing-fight one on one only.

Take care of each other. (Owen and MacKenzie, 2004: 159)

The inmate codes have changed from when early researchers began writing about prisoner subcultures. One result seems to be that inmate solidarity has eroded considerably. Hassine (1999) talks about a code that has changed as a result of younger and more violent offenders entering prisons. Such a code that has changed throughout time is connected with prescriptions such as:

Don't gamble.

Don't mess with drugs.

Don't mess with homosexuals.

Don't steal.

Don't borrow or lend, and you might survive. (Hassine, 1999: 42)

Special norms of behaviour exist also in Polish prison subculture. In some prisons these norms are harder, in the others they become weaker. In Polish literature the inmate codes are described and labeled by a number of authors (see Braun, 1955; Kosewski, 1977; Wawszczyk, Wawrzyniak, Różański, 1994). Szaszkiewicz (1997) divides the inmate codes into three groups, these are:

1. Norms formulated in order to condemn particular groups of people.

\section{Examples:}

Don't make friends with jailers.

You can't become "human" if your father is a police officer or a jailer.

Don't shake hands with "victims"

2. Norms protecting group solidarity.

\section{Examples:}

Don't shake hands with anybody who is not in "human" group.

"Human" must share any goods such as cigarettes or tea with other humans.

"Humans" eat together at the table and "victims" (also "faggots") eat apart.

3. Norms protecting the honour of "humans"

Don't pick up rubbish with hands. 


\section{Don't rob "humans"}

Don't clean lavatory with hands. You can use only a brush. (Szaszkiewicz, 1997: 49-60)

To sum up, prisoners are dependent on and in some way determined by all kinds of norms (formal and informal norms). In prison everything is predetermined and a prisoner is not allowed to do anything by himself. If he breaks the rules, there are other rules formulated in order to show how to punish for breaking the rules of "grypserka". According to Einat and Einat (2000: 309) "this code is directly linked to the process of socialization and adaptation to prison life". The inmate code has universal elements that cut across all correctional facilities because the normative society, its attributes, and its delegates are inherent opponents of prisoners (Hensey, Tewksbury, Castle, 2003: 290).

There is a significant connection between the behavioural aspect of the above codes and the linguistic aspects. The exemplified codes help to emphasize unity of prisoners against correctional workers. Such norms are taught using "grypserka" antilanguage and both terms are inseparable since the ability to speak "grypserka" is one of many norms to study in prison.

\section{Prison terminology: Comparing the Polish and American Case}

Hargan (1934) stated in his early study that the prison slang had a purpose. It was a secret code against outsiders and prison officials and, therefore acted to reinforce solidarity. However, guards usually know the meaning of prisoner slang as well as the prisoners do, and may use it to a significant degree (Lerner 2002). Garabedian (1964) and Sykes (1958) claim that prisoner argot serves as a symbolic expression of group loyalty, the use of which serves as a measure of integration and allegiance to the inmate subculture. One may define prison slang as a variation of street jargon because a number of the terms can be found in any street slang. Prison slang is a language of prisoners and is regarded as an important part of the prison subculture.

Prison slang terms tend to change over time and they vary between institutions, and across different regions of the countries. According to Dumond (1992: 138), “The terms may have changed somewhat over the decades, prison slang defines sexual habits and inmates' status simultaneously, using homosexuality as a means of placing individuals within the inmate caste system". Prison slang is a dynamic, constantly evolving entity. Some of the earliest examples of prison slang may have very different meanings today, if they are used at all. Prison slang is used in all prison subcultures around the world, with special terms designated for everything from prison food to guards, and especially the different types of inmates and roles in the prison setting (Pollock, 2005: 96). There is evidence that prison argot is still evolving. Clemmers' (1958) contribution to prison argot terminology is one of the earliest. He labeled some prison slang terms and provided their definitions. In 2001 Glenn provided a long list of slang terms in his time when he used to work as a prison warder. Let us compare those two lists of prison slang terms provided by Clemmer (1958) and Glenn (2001) in order to estimate how their meanings have changed over time. Their contributions are listed below. 


\section{Clemmer (1940)}

policeman

to masturbate

$$
\text { drug }
$$

prison warder clown

hand jig

junk

hack (especially a night warden)

\section{Glenn (2001)}

chota

kill

chiva

boss

It should be noted that prison slang terms vary by place and institution as well. Moreover, there are a number of prison terms for one word such as "crap", "H", "smack" and "brown" for cocaine. Perhaps, argot for marijuana might be the most numerous starting with traditional "grass", "Mary Jane" or "Aunt Mary" and ending with "mutha" and "lubage". Now, I would like to compare some terms of American prison argot and Polish "grypserka" to investigate what are the names of differ-

\begin{tabular}{|c|c|c|c|}
\hline & $\begin{array}{c}\text { American } \\
\text { prison argot }^{3}\end{array}$ & $\begin{array}{c}\text { Polish } \\
\text { "grypserka"4 }\end{array}$ & $\begin{array}{c}\text { Literal } \\
\text { meaning }\end{array}$ \\
\hline a child molester & tree jumper & majciarz & $\begin{array}{c}\text { the one who wears } \\
\text { panties }\end{array}$ \\
\hline $\begin{array}{c}\text { one newly arrived } \\
\text { to prison }\end{array}$ & fish & noworodek & infant \\
\hline a doctor & croaker & piguła & pill \\
\hline a prison warden & boss & fortepian & piano \\
\hline tattoo & ink & dziara & edging \\
\hline prostitute & canteen punk & ćma & moth \\
\hline
\end{tabular}
ent slang terms in Polish and American argot and to what extent they are different.

3 Glenn, Lon B. (2001) “Texas prisons: the largest hotel chain in Texas”. Eakin Press.

4 Szaszkiewicz, Maciej (1997) „Tajemnice grypserki”. Kraków: Wydawnictwo Instytutu Ekspertyz Sądowych 
The special terminology of prison inmates is largely different from that of non-inmates or "nonhumans" in Polish "grypserka". The prison slang provides parameters of understandings for constructing a social and cultural environment. Nowhere is this clearer than in correctional institutions, where inmates live, think, and function within the framework defined by the argot (Bondesson 1989). Therefore, Einat and Einat (2000: 310-311) labeled several functions of the prison slang:

- The need to be different and unique

- Alleviation of feelings or rejection and refusal

- Facilitation of social interactions and relationships

- Declaration of belonging to a subculture or social status

- A tool of social identification leading to a sense of belonging to a group

- Secrecy

These argot functions " help to define the treatment which an inmate is likely to receive from other inmates and corrections officers" (Dumond 1992: 138).

\section{Conclusions}

The prison argot and the secret Polish "grypserka" as well which characterize prison subcultures are inseparable parts of the concept of prisonization as well as the development of different inmate codes. The earlier research and the present study on argot functions are clear. They reflect and consolidate organization, hierarchy in prison milieu and language of the prison subculture. The research reveals that American and Polish inmate codes are different from each other. American prisoners follow their own codes and prison rules. Polish grypserka assigned different naming for various words. For example, a doctor is called a croaker in American prison slang and a pill in grypserka.

To coexist in prison, inmates must learn prison argot terms in order to communicate with each other, declare belonging to "humans" or facilitate of social interactions. Slang is developed to make people feel different and distinguish them from community but prison argot may be functioning as an entertaining activity.

\section{References}

Archer, Thomas. 1985. The pauper, the thief, and the convict. New York: Garland Pub.

Becker, Howard. 1963. Outsiders: Studies in the Sociology of Deviance. New York: The Free Press.

Bondesson, Ulla. 1989. Prisoners in prison societies. New Brundswick, NJ: Transaction Publishers.

Braun, Kazimierz. 1975. „Drugie życie wśród skazanych młodocianych”, in: Negatywne zjawiska podkultury więziennej, środki i sposoby przeciwdziałania. Warszawa: Wydawnictwo CZSW.

Clarke, Garry. 1981. "Defending Ski-Jumpers: A Critique of Theories of Youth Subcultures", in: Thornton, Sarah and Gelder, Ken (eds.), The Subcultures Reader. London and New York: Routledge.

Clemmer, Donald. 1958. The prison community. Holt, Rinehart and Winston. 
Cressey, Donald, R. 1932. The Taxi-Dance Hall. New York: Greenwood Press.

Crimp, Douglas and Rolston, Adam. 1980. AIDS DemoGraphics. Seattle: Bay Press.

Cohen, Albert K. 1955. Delinquent boys: the culture of the gang, Glencoe. Ill: Free Press.

Czapow, Czesław and Jedlewski Stanisław. 1971. Pedagogika resocjalizacyjna. Warszawa: PWN.

Dickens, Charles. 1984. The Adventures of Oliver Twist. London: Folio Society.

Dumond, Robert W. 1992. “The sexual assault of male inmates in incarcerated settings". International Journal of the Sociology of Law 20: 135-157.

Einat, Tomer. 2000. "Inmate Argot as an expression of prison subculture: the Israeli case", The Prison Journal 80: 309-325.

Fonarow, Wendy. 1995. Empire of dirt: The aesthetics and rituals of British indie music. Middletown, Conn.: Wesleyan University Press.

Fowler, Henry Watson. 1964. "Subculture", in: The Concise Oxford Dictionary of Current English. London : Clarendon Press.

Garabedian, Peter G. 1964. "Social Roles in a Correctional Community", Journal of Criminal Law and Criminology 55 (September): 338-350.

Giallombardo, Rose. 1966. Society of Women: A Study of a Women's Prison. New York: John Wiley \& Sons.

Glenn, Lon B. 2001. Texas prisons: the largest hotel chain in Texas. Eakin Press.

Goffman, Irving. 1961. Asylums. Garden City. N.Y.: Doubleday.

Hebdige, Dick. 1979. Subculture: the meaning of style. Methuen, London.

Hargan, James. 1934. "The psychology of prison language”. Journal of abnormal and social psychology 30 (October-December): 359-361.

Hassine, Victor. 1999. Life without parole: living in prison today. Roxbury Pub. Co.

Hensel, Christopher, Tewksbury Richard \& Castle, Tammy. 2003. "Characteristics of Prison Sexual Assault Targets in Male Oklahoma Correctional Facilities“, Journal of Interpersonal Violence 18: 595-606.

Hodkinson, Paul. 2003. "Net.Goth: Internet Communication and (sub) Cultural Boundaries", in: Muggleton, David and Weinzierl, Rupert (eds.) The post-subcultures reader. New York: Berg. Jenkins, Henry. 1992. Textual Poachers. London: Routledge.

Kosewski, Marek. 1977. Agresywni przestępcy. Warszawa: Wiedza Powszechna.

Lerner, Jimmy A. 2002. You Got Nothing Coming: Notes From a Prison Fish. Broadway Books.

Maffesoli, Michael. 1996. The Time of the Tribes: The Decline of Individualism in Mass Society. London: Thousand Oaks, Calif.: Sage.

Mayhew, Augustus. 1851. "Paved with gold", or, "The romance and reality of the London streets: 'an unfashionable novel"'. London: Chapman and Hall.

Michaels, Leonard \& Ricks Christopher. 1980. The state of the language. University of California Press.

Moczydłowski, Paweł. 1988. Drugie życie w instytucji totalnej. Warszawa: Wydawnictwo Uniwersytetu Warszawskiego. 
Morawski, Jerzy. 1968. „Młodociani grypserzy. (Pragmatyczne i semantyczne aspekty gwary więziennej)", Przegląd Penitencjarny VI nr 4/20: 39-44.

Morrison, Arthur. 1946. A child of the Jago. Harmondsworth, Middlesex: Penguin Books.

Owen, Barbara and MacKenzie, Doris. 2004. “The mix: The culture of imprisoned women”, in: M. Stohr \& C. Hemmens (eds.) The inmate prison experience. Upper Saddle River, NJ: Pearson, 152-172.

Park, Robert E. 1925. The City. University of Chicago Press, London.

Pollock, Joycelyn M. 2005. Prisons Today and Tomorrow. Jones \& Bartlett Learning.

Przybyliński, Sławomir. 2005. Podkultura więzienna - wielowymiarowość rzeczywistości penitencjarnej. Kraków: Impuls.

Schrag, Clarence. 1944. Social Role Types in a Prison Community. Unpublished Master's Thesis. University of Washington.

Stallybrass, Peter and White, Allon. 1986. The politics and poetics of transgression. London: Methuen.

Stępniak, Klemens. 1973. „Nazwy gwary złodziejskiej”, Poradnik Językowy 4: 210-222.

Sykes, Gresham M. 1958. The society of captives: a study of a maximum security prison. Princeton University Press.

Sykes, Gresham M. \& Messinger, Sheldon L. 1960. “The Inmate Social System”, in: R. Cloward (ed.), Theoretical studies in social organization of the prison. New York: Social Science Research Council.

Szaszkiewicz, Maciej. 1997. Tajemnice grypserki. Kraków: Wydawnictwo Instytutu Ekspertyz Sądowych.

Thornton, Sarah. 1997. "General Introduction”, in: Thornton, Sarah and Gelder, Ken (eds.), The Subcultures Reader. London and New York: Routledge.

Thornton, Sarah and Gelder, Ken. 1997. The Subcultures Reader. London and New York: Routledge.

Thrasher, Frederic Milton. 1963. The gang: A study of 1,313 gangs in Chicago. Chicago: University of Chicago Press.

Ueno, Toshiya. 2003. "Unlearning to Raver: Techno-Party as the Contact Zone in Trans-local Formations", in: Muggleton, David and Weinzierl, Rupert (eds.) The Post-Subcultures Reader. New York: Berg.

Valdivia, Angharad. 2003. "Racial Hybridity: Latinias/os as te Paradigmatic transnational Postsubculture", in: Muggleton, David and Weinzierl, Rupert (eds.) The Post-Subcultures Reader. New York: Berg.

Wawszczyk W., Wawrzyniak L., Różański Z. 1994. „Charakter i struktura grup nieformalnych w zakładach penitencjarnych i Rejonowym Areszcie Śledczym w Katowicach”, in: „Materiały z konferencji”. Kalisz: Wydawnictwo CZZK.M.S.

Young, Jock. 1971. “The subterranean world of play”, in: Thornton, Sarah and Gelder, Ken (eds.) The Subcultures Reader, London and New York: Routledge. 